\title{
Electrophysiological evaluation of carpal tunnel syndrome female patients after vitamin $D$ replacement
}

\author{
Avaliação eletrofisiológica de pacientes do sexo feminino com síndrome do túnel do carpo \\ após reposição de vitamina $D$
}

Hikmet SAÇMACI', Nermin TANIK', Özlem BALBALOĞLU², Tülin AKTÜRK'1, Levent Ertuğrul iNAN

\begin{abstract}
Objective: The effects of vitamin D on the central and peripheral nervous system continue to be investigated today. In the present study, we aimed to evaluate pain and electrophysiologic response in patients with carpal tunnel syndrome (CTS) who have undergone replacement therapy due to vitamin D deficiency. Methods: Fifty female patients diagnosed with mild and moderate CTS and accompanied by vitamin $D$ deficiency were included in this study. Nerve conduction study (NCS) was performed before and after vitamin D replacement, and the patient's pain was evaluated with Visual Analogue Scale (VAS). Results: When NCS were compared before and after treatment, there was a statistically significant improvement in the median distal sensory onset latency (DSOL) and sensory conduction velocity (CV) and motor distal latencies (DML) values ( $p=0.001 ; p<0.001 ; p=0.001$, respectively). At the same time, there was a decrease in the VAS values in patients $(p<0.001)$. When the two groups were compared there was an improvement in DSOL and sensory CV in both groups, but in DML only in moderate CTS group. Conclusion: In this study, it was shown that mild and moderate CTS patients had an improvement in pain and electrophysiological parameters after vitamin D replacement. Replacing vitamin D in early stages of CTS may be beneficial.
\end{abstract}

Keywords: carpal tunnel syndrome; vitamin D treatment; nerve conduction velocity.

RESUMO

Objetivo: Os efeitos da vitamina D no sistema nervoso central e periférico continuam sendo investigados atualmente. Neste estudo, objetivamos avaliar a dor e a resposta eletrofisiológica em pacientes com síndrome do túnel do carpo (STC) submetidos a terapia de reposição devido à deficiência de vitamina D. Métodos: Cinquenta pacientes do sexo feminino diagnosticadas com STC leve e moderada e acompanhadas de deficiência de vitamina D foram incluídas neste estudo. 0 estudo da condução nervosa (ECN) foi realizado antes e após a reposição da vitamina D, e a dor do paciente foi avaliada com a Escala Visual Analógica (EVA). Resultados: Quando a ECN foi comparada antes e após o tratamento, houve uma melhora estatisticamente significativa na latência mediana do início sensorial distal (DSOL) e nos valores de velocidade de condução sensorial (VC) e latência distal motora ( $L D M)$ ( $p=0,001 ; p<0,001 ; p=0,001$, respectivamente). Ao mesmo tempo, houve uma diminuição dos valores da EVA nos pacientes ( $p<0,001)$. Quando os dois grupos foram comparados, houve uma melhora no DSOL e no VC sensorial em ambos, mas no LDM apenas no grupo STC moderado. Conclusão: Neste estudo, foi demonstrado que pacientes com STC leve e moderada apresentaram melhora da dor e parâmetros eletrofisiológicos após a reposição de vitamina D. A substituição da vitamina D nos estágios iniciais da STC pode ser benéfica.

Palavras-chave: síndrome do túnel carpal; tratamento com vitamina D; velocidade de condução sensorial.

Carpal tunnel syndrome (CTS) is the most common peripheral nerve entrapment caused by an impairment in the nerve functions, due to the compression of the median nerve at the wrist level ${ }^{1,2}$. CTS can be caused by systemic, anatomic and idiopathic causes ${ }^{3}$. Treatment is medical (splinting, steroid injections) or surgical decompression of carpal tun$\mathrm{nel}^{2}$. Vitamin D deficiency is an independent risk factor, that increases the symptoms of $\mathrm{CTS}^{4}$.

Vitamin D deficiency is worldwide seen as a pandemic condition, and its main cause is inadequate synthesis ${ }^{5}$.

\footnotetext{
${ }^{1}$ Yozgat Bozok University Faculty of Medicine, Department of Neurology, Yozgat, Turkey.

${ }^{2}$ Yozgat Bozok University Faculty of Medicine, Department of Physical Therapy and Rehabilitation, Yozgat, Turkey.

Hikmet SAÇMACI (ID) https://orcid.org/0000-0003-1480-0562; Nermin TANIK (iD) https://orcid.org/0000-0002-7567-9244;

Özlem BALBALOĞLU (ID) https://orcid.org/0000-0003-2813-3406;Tülin AKTÜRK (iD) https://orcid.org/0000-0003-1818-1578;

Levent Ertuğrul iNAN (iD https://orcid.org/0000-0002-2441-0624
}

Correspondence: Hikmet Saçmacı; Bozok University, Faculty of Medicine, Department of Neurology; TR-66200, Bozok, Turkey; E-mail: hsacmaci@hotmail.com Conflict of interest: Thre is no conflict of interes to declare.

Received on May 13, 2019; Received in its final form on November 3, 2019; Accepted on November 12, 2019. 
Vitamin D is a steroid molecule and it is synthesized from 7-dehydrocholesterol by the action of ultraviolet $\mathrm{B}$ rays in the epidermis ${ }^{6}$. Experimental animal model studies demonstrated that vitamin D increases myelination after peripheral nerve injury and reduces neuronal injury ${ }^{7,8}$. Vitamin D deficiency may cause hyperinnervation and hypersensitivity in the nerve fibers and increases pain sensation and pain perception in the pathological process 9 .

Vitamin D3 and Vitamin D2, which accelerate the neuronal regeneration process, were approved by the $\mathrm{FDA}^{7}$. The role of calcitriol in treatment of the nervous system will be better understood if it is noted that the nervous system and ectoderm have a common embryologic origin ${ }^{7}$. Therapeutic and protective effects of vitamin $\mathrm{D}$ are reduction in oxidative stress and provision of neuroplasticity and neuroprotection ${ }^{10,11}$.

In recent years, the role of vitamin D deficiency in the etiology of acute-chronic central and peripheral neurological diseases has been investigated, and the effectiveness and treatment of vitamin D replacement has been demonstrated. For example, in diabetic sensory neuropathy, topical and oral vitamin $\mathrm{D}$ therapy reduce the pain ${ }^{12}$. The role of vitamin D in the recovery of CTS remains unknown. In this study, we aimed to evaluate the effect of vitamin $D$ replacement on pain and electrophysiological response in CTS patients with vitamin deficiency.

\section{METHODS}

This cohort study was retrospectively conducted with CTS patients, who had a diagnosis of vitamin D deficiency and were admitted to the Yozgat Bozok University departments of Neurology and Physical Therapy and Rehabilitation from 2017 to 2018. Patients with CTS who were not on neuropathic pain treatment and could not use splint because of discomfort were selected. Patients with a vitamin D level above $20 \mathrm{ng} / \mathrm{mL}$, who did not use vitamin therapy regularly, and patients receiving recurrent vitamin treatments were excluded from the study. Patients who have severe CTS were the main exclusion criteria for this study. Other exclusions were patients on dialysis, malignancy, severe liver failure, coronary artery disease, cerebrovascular disease, diabetes mellitus, hypothyroidism, hyperparathyroidism, and/or vitamin B12 deficiency, cervical hernia, prior CTS surgery, or steroid injections. For each patient, body mass index (BMI) was calculated according to the World Health Organization (WHO) classification, based on patient's height and weight.

The Ethics Committee gave its approval before the study was started. It was conducted according to the principles of the Declaration of Helsinki.

\section{Biochemical analysis}

Laboratory examinations, including a screening analysis of 25-dihydroxyvitamin D levels, were performed using venous blood samples from 9:00 to 10:00. All serum 25-dihydroxyvitamin D ( $\mathrm{ng} / \mathrm{ml})$ concentrations were analysed using an electrochemiluminescent immunosassay technique with Coba e601 analyzer (Roche Diagnostics GmbH; Mannheim, Germany). In all adults with vitamin D deficiency, 6000 IU/day or $50.000 \mathrm{IU} /$ week of vitamin D2 or vitamin D3 was given for eight weeks and also supplemented in maintenance therapy.

\section{Assessment of peripheral neuropathy and pain}

\section{Visual analogue scale}

Visual Analogue Scale (VAS) was used to measure the pain score: 1-3: mild; 4-6: moderate; 7-8: severe; 9-10: extremely severe ${ }^{13}$. Symptom duration, pain severity, and methodology of vitamin $\mathrm{D}$ treatment were questioned in face-to-face interviews.

\section{Electrophysiological evaluation}

All CTS patients who regularly used 3-month vitamin D treatment underwent conventional sensory and motor nerve conduction studies, performed by the neurologist who was blinded to the first nerve conduction study (NCS) results. Median and ulnar nerves were studied in both limbs, with respect to sensory and motor conduction studies using a Medelec Synergy electromyography (EMG) machine (Medelec Synergy, Oxford Instruments, Surrey, UK). The filter settings used a 20-2,000 $\mathrm{Hz}$ bandpass for the sensory nerve studies and a 2-10,000 Hz bandpass for the motor nerve studies. The sweep speed was set at $1 \mathrm{~ms}$ per division. The bar electrodes recordings were used for motor nerve studies and sensory studies. A ground electrode was appropriately placed between the stimulating and recording electrodes. The skin temperature of the hand was maintained at or above $32^{\circ} \mathrm{C}$. Nerve conduction studies have been performed using standard techniques, and bipolar superficial electrodes based on a guideline ${ }^{14}$. Sensory nerve conduction studies were performed with antidromic methods. Recordings were performed with supramaximal stimulation. All the studies were performed in a warm room, with the temperature maintained at $26-28^{\circ} \mathrm{C}$. The age and temperature of patients were considered in the diagnostic parameters of CTS by NCS evaluation ${ }^{15}$.

Median distal sensory onset latency (DSOL): the stimulation delivered on the median nerve at the wrist activates sensory action potentials at the index finger. We used a fixed $13 \mathrm{~cm}$ distance from the bar recording electrode. The cutoff value was $3.5 \mathrm{~ms}$.

Median motor distal latency (DML): The median nerve stimulation was delivered at the wrist to activate the compound muscle action potential at the thenar eminence. We used a fixed $7 \mathrm{~cm}$ distance from the bar recording electrodes that were placed over the belly of the abductor pollicis brevis (APB) muscle (the recording electrode), and just distal to the metacarpophalangeal joint (the reference electrode). The cutoff value was $4.4 \mathrm{~ms}$. 
All NCS's were performed on the same device and by the same person, using the same technique; the NCS and $25(\mathrm{OH}) \mathrm{D}$ results were evaluated by the blind neurologist. Patients were classified as follows: mild CTS (median sensory conduction velocity [SCV] slowed in the fingerwrist nerve segment with normal DML), moderate CTS (median SCV slowed in the finger-wrist nerve segment with increased DML).

\section{Statistical analysis}

All analyses were carried out using the Statistical Package for the Social Sciences (SPSS) program for Windows (version 20.0, released in 2011; IBM Corp. Armonk, New York, USA). The main characteristics of patients were evaluated with descriptive and analytical statistics. Categorical variables were compared by chi-square test. The mean values of the continuous variables were compared using the independent-samples or paired-samples Student's t-test as appropriate. The normal distribution of continuous variables was tested using a Kolmogorov-Smirnov test. Normally distributed paired data were analyzed with a paired t-test, whereas skewed paired data were analyzed using the Wilcoxon test. Data were expressed as mean $\pm \mathrm{SD}$ or median (minimummaximum). The Spearman correlation coefficient was used to evaluate the correlation between the improvement in $25(\mathrm{OH})$ $\mathrm{D}$ and the NCS. P-values $<0.05$ were considered to be statistically significant.

\section{RESULTS}

Fifty female patients with vitamin D deficiency were included in the study with results of bilateral median nerve conduction studies. Among the subjects, there were 45 hands with mild CTS (54.87\%), and 37 hands with moderate CTS (45.12\%). In both groups, the age, VAS score, BMI, vitamin D levels of CTS patients were summarized in Table 1. The mean age was $48.04 \pm 6.03$ (range 36-60) in the mild CTS group, and 45.97 \pm 7.97 (range 31-56) in the moderate CTS group. BMI was $30.30 \pm 5.99$ in the mild CTS group and $31.70 \pm 5.73$ in the moderate CTS group, and there was no statistically significant difference between the mild and moderate CTS groups regarding their demographic characteristics $(\mathrm{p}>0.05)$.

Considering all subjects, the pre- and post-treatment vitamin D levels were $11.70 \pm 4.09$ (range 3.30-20.00) and $35.48 \pm 15.30$ (range 14.90-60.00), respectively. The improvement in vitamin $\mathrm{D}$ levels after a 3-month treatment was found to be statistically significant $(\mathrm{p}<0.001)$.

Baseline nerve conduction values and control values (at the third post-treatment month) of the mild and moderate CTS groups are presented in Tables 2 and 3. In the mild CTS group, shortening of DSOL and increase in conduction velocity were statistically significant $(\mathrm{p}=0.003 ; \mathrm{p}<0.001$, respectively). In moderate CTS group, sensory amplitudes and sensory conduction velocity increased, and there was a shortening in DML ( $\mathrm{p}=0.037 ; \mathrm{p}=0.005 ; \mathrm{p}=0.001$, respectively). Improvements in other parameters were not statistically significant in two groups $(\mathrm{p}>0.05)$.

Table 1. Demographic characterics of mild and moderate CTS groups at baseline.

\begin{tabular}{lccc}
\hline Variables & $\begin{array}{c}\text { Mild CTS } \\
(\mathrm{n}=45)\end{array}$ & $\begin{array}{c}\text { ModerateCTS } \\
(\mathrm{n}=37)\end{array}$ & $p$-value \\
\hline Age (years) & $48.04 \pm 6.03$ & $45.97 \pm 7.97$ & 0.380 \\
\hline $\begin{array}{l}\text { Body mass } \\
\text { index }\left(\mathrm{kg} / \mathrm{m}^{2}\right)\end{array}$ & $30.30 \pm 5.99$ & $31.70 \pm 5.73$ & 0.288 \\
\hline $\begin{array}{l}\text { Serum } \\
\text { vitamin D } \\
\text { level }(\mathrm{ng} / \mathrm{mL})\end{array}$ & $11.75 \pm 4.53$ & $11.64 \pm 3.55$ & 0.727 \\
$\begin{array}{l}\text { VAS } \\
\text { Vuration of }\end{array}$ & $6.64 \pm 1.13$ & $7.24 \pm 0.85$ & 0.051 \\
$\begin{array}{l}\text { symptoms } \\
\text { (months) }\end{array}$ & $5.97 \pm 2.27$ & $13.59 \pm 2.24$ & $<0.001$ \\
\hline
\end{tabular}

VAS: visual analog scale; CTS: carpal tunnel syndrome; bold values are statistically significant.

Table 2. Nerve conduction studies results before and after 3 months of vitamin D suppplementation in the mild CTS.

\begin{tabular}{|c|c|c|c|}
\hline $\begin{array}{l}\text { Mild CTS } \\
\text { patients }\end{array}$ & $\begin{array}{l}\text { Before } \\
\text { replacement }\end{array}$ & $\begin{array}{c}\text { After } \\
\text { replacement }\end{array}$ & $p$-value \\
\hline $\begin{array}{l}\text { Median } \\
\text { distal } \\
\text { sensory } \\
\text { onset latency } \\
\text { (DSOL) (ms) }\end{array}$ & $2.93 \pm 0.26$ & $2.81 \pm 0.36$ & 0.003 \\
\hline $\begin{array}{l}\text { Median } \\
\text { distal motor } \\
\text { latency } \\
\text { (DML) (ms) }\end{array}$ & $3.39 \pm 0.28$ & $3.51 \pm 0.84$ & 0.138 \\
\hline $\begin{array}{l}\text { Sensory } \\
\text { amplitude } \\
(\mu \mathrm{V})\end{array}$ & $26.28 \pm 4.95$ & $26.77 \pm 6.73$ & 0.61 \\
\hline $\begin{array}{l}\text { Motor } \\
\text { amplitude } \\
\text { (wrist) (mV) }\end{array}$ & $8.84 \pm 1.79$ & $9.20 \pm 2.04$ & 0.21 \\
\hline $\begin{array}{l}\text { Median } \\
\text { sensory } \\
\text { conduction } \\
\text { velocity }(\mathrm{m} / \mathrm{s})\end{array}$ & $43.67 \pm 3.11$ & $47.25 \pm 5.77$ & $<0.001$ \\
\hline $\begin{array}{l}\text { Median } \\
\text { motor } \\
\text { conduction } \\
\text { velocity }(\mathrm{m} / \mathrm{s})\end{array}$ & $55.74 \pm 2.88$ & $55.71 \pm 2.79$ & 0.94 \\
\hline $\begin{array}{l}\text { Serum } \\
\text { vitamin D } \\
\text { level }(\mathrm{ng} / \mathrm{mL})\end{array}$ & $11.75 \pm 4.53$ & $37.97 \pm 16.02$ & $<0.001$ \\
\hline VAS & $6.64 \pm 1.13$ & $4.53 \pm 0.69$ & $<0.001$ \\
\hline
\end{tabular}

VAS: visual analog scala; CTS: Carpal tunnel syndrome; bold values indicate a statistically significant difference with a p-value under 0.05 . 
For all subjects, when the correlation between vitamin D and electrophysiological values after treatment was examined, the shortening in DSOL and DML showed a moderately negative correlation $(\mathrm{p}=0.009$, rho $=-0.287 ; \mathrm{p}=0.013$, rh $\mathrm{o}=-0.272$ ), and the increase in sensory conduction velocity showed a moderately positive correlation $(\mathrm{p}=0.019$, rho=0.258). There was no significant correlation between other electrophysiological values and vitamin D levels.

In the evaluation of the electrophysiological improvement before and after the treatment in both groups, NCS recordings of 36 hands improved neurophysiologically (43.9\%) as well as pain scores $(\mathrm{p}<0.001)$. Of these, 28 were from the mild CTS group, and 8 were from the moderate CTS group $(62.2 \%$, $21.6 \%)$. When NCS was repeated after 3 months of treatment, 25 patients $(67.6 \%)$ had moderate CTS findings and 16 patients $(35.6 \%)$ had mild CTS findings. All recovery percentages in two groups are presented in Table 4.

\section{DISCUSSION}

When the electrophysiological measurements before and after treatment were evaluated in general, we found a neurophysiological improvement. In both groups, improvements in VAS and serum vitamin D levels after the treatment were found to be highly significant.

Table 3. Nerve conduction studies results before and after 3 months of vitamin D suppplementation in the moderate CTS.

\begin{tabular}{lccc}
\hline $\begin{array}{l}\text { Moderate CTS } \\
\text { patients }\end{array}$ & $\begin{array}{c}\text { Before } \\
\text { replacement }\end{array}$ & $\begin{array}{c}\text { After } \\
\text { replacement }\end{array}$ & $p$-value \\
\hline $\begin{array}{l}\text { Median distal } \\
\text { sensory onset } \\
\text { latency (DSOL) } \\
\text { (ms) }\end{array}$ & $3.54 \pm 0.71$ & $3.34 \pm 0.75$ & 0.06 \\
$\begin{array}{l}\text { Median distal } \\
\text { motor latency } \\
\text { (DML) (ms) }\end{array}$ & $4.72 \pm 0.80$ & $4.50 \pm 1.46$ & 0.001 \\
$\begin{array}{l}\text { Sensory } \\
\text { amplitude ( } \mu \text { V) }\end{array}$ & $17.98 \pm 6.62$ & $21.42 \pm 10.20$ & 0.037 \\
$\begin{array}{l}\text { Motor amplitude } \\
\text { (wrist) (mV) }\end{array}$ & $8.84 \pm 1.79$ & $9.20 \pm 2.04$ & 0.21 \\
\hline $\begin{array}{l}\text { Median sensory } \\
\text { conduction } \\
\text { velocity (m/s) }\end{array}$ & $37.27 \pm 5.46$ & $40.47 \pm 7.31$ & 0.005 \\
$\begin{array}{l}\text { Median motor } \\
\text { conduction } \\
\text { velocity (m/s) }\end{array}$ & $55.00 \pm 2.71$ & $54.50 \pm 3.56$ & $0.71 *$ \\
\hline $\begin{array}{l}\text { Serum vitamin D } \\
\text { level (ng/mL) }\end{array}$ & $11.64 \pm 3.55$ & $32.45 \pm 13.99$ & $<0.001$ \\
\begin{tabular}{l} 
VAS \\
\hline
\end{tabular} & $7.45 \pm 0.69$ & $6.64 \pm 0.85$ & $<0.001$ \\
\hline
\end{tabular}

VAS: visual analog scala; CTS: Carpal tunnel syndrome; bold values indicate a statistically significant difference with a p-value under 0.05 .
In the evaluation of mild and moderate CTS groups regarding response to vitamin $\mathrm{D}$ replacement, 36 patients (43.9\%) were seen to reach normal electrophysiological values at the follow-up visit 3 months later (28 patients-mild, $62.2 \%$; 8 patients-moderate, $21.6 \%)$. Pain, numbness and tingle symptoms persisted in 16 patients (35.6\%) in the mild CTS group and in 25 patients $(67.6 \%)$ in the moderate CTS group.

In recent years, efforts have been made to identify treatment protocols to effectively heal peripheral nerve diseases in which nerve injury is present. Although steroid injections and splint treatment have limited effects, reducing carpal tunnel edema and preventing the onset of axonal damage are the most important goals of the CTS treatment, especially in mild CTS patients ${ }^{2}$. In a study evaluating the nerve conducitions before and after vitamin D treatment, no clear recovery findings were observed in this study, because of the axonal damage in the pathophysiological disorder caused by diabetes ${ }^{12}$. A treatment option, which is developed to enhance median nerve regeneration in CTS, has not been included in the guidelines yet. Neither Vit D nor corticosteroids are proved to enhance nerve repair, and axonal damage is caused by compression and nerve degeneration ${ }^{2}$.

Our findings are similar to those from a study by Montava et al., in which facial nerve injury was induced in an experimental animal model. After $200 \mathrm{IU} / \mathrm{kg} /$ day oral vitamin D treatment, calcitriol induced functional recovery and myelination starting from the $6^{\text {th }}$ week, and myelination response was seen electrophysiologically starting from the $12^{\text {th }}$ week ${ }^{7}$. It has also been shown that in rat models with peroneal nerve injury, cholecalciferol and calcitriol induce peroneal nerve healing ${ }^{8}$. However, they found more prominent recovery in the facial nerve neuropraxia model compared to peroneal injury model. They attributed this effect to some of the unique features of the facial nerve ${ }^{16,17}$.

Chabas et al. induced the peroneal nerve injury in two different experimental animal models and found a significant contribution of cholecalciferol and calcitriol to locomotor and electrophysiological healing. There was an increase in nerve myelination proximal and distal to

Table 4. Alteration of mild and moderate CTS groups before and after treatment, according to electrophysiological values with table of $2 \times 2$.

\begin{tabular}{lccc}
$\begin{array}{l}\text { Post } \\
\text { treatment } \\
\text { recordings of } \\
\text { NCS values }\end{array}$ & $\begin{array}{c}\text { Pre- } \\
\text { treatment } \\
\text { mild CTS } \\
(\mathrm{n}=45)\end{array}$ & $\begin{array}{c}\text { Pre- } \\
\text { treatment } \\
\text { moderate } \\
\text { CTS }(\mathrm{n}=37)\end{array}$ & $\begin{array}{c}\text { Total } \\
\text { recordings of } \\
\text { CTS }(\mathrm{n}=82)\end{array}$ \\
\hline $\begin{array}{l}\text { Normal NCS } \\
\mathrm{n}(\%)\end{array}$ & $28(62.2 \%)$ & $8(21.6 \%)$ & $36(43.9 \%)$ \\
$\begin{array}{l}\text { Mild CTS } n \\
(\%)\end{array}$ & $16(35.6 \%)$ & $25(67.6 \%)$ & $41(50 \%)$ \\
$\begin{array}{l}\text { Moderate } \\
\text { CTS n }(\%)\end{array}$ & $1(2.2 \%)$ & $4(10.8 \%)$ & $5(6.1 \%)$ \\
\hline
\end{tabular}

NCS: nerve conduction study; CTS: Carpal tunnel syndrome. 
the injury. Besides that, genes inducing axonogenesis and myelination associated with calcitriol were activated after vitamin $\mathrm{D}$ therapy. As a result, new axons and myelination were increased in the proximal and distal peroneal nerve stumps ${ }^{8,18}$.

Vitamin D increases the production of NGF, neurotrophin 3 and glial cell line- derived neurotrophic factor (GDNF), whereas neurotrophin 4 expression decreases ${ }^{8}$. Vitamin D receptors are commonly expressed in neuronal tissues, because they are needed for the development of the central and peripheral nervous system beginning from the embryonic stage (). Vitamin D induces neurotrophin expression and enhances axon development. It also plays an immunomodulatory role in Wallerian degeneration ${ }^{19,20}$.

In an animal study in which a neuropathic pain model was developed, it was shown that hyperalgesia and allodynia decreased after vitamin D supplementation, especially in the 21-day acute phase ${ }^{21}$. However, the necessity of clinical trials to find effective dose in the treatment was emphasized. When its role in the mechanism of pain is considered, vitamin $\mathrm{D}$ prevents progression of the inflammatory cascade in chronic pain. TNF and macrophage-microglia, which cause sensitization of the peripheral and central nervous system and inhibit the stimulating mechanism ${ }^{22}$. Donato and colleagues emphasized that vitamin D plays a role in anti-VEGF agent and it may be the first line treatment because it is cheap and effective in the treatment of CTS 4 .

Akyuz et al. evaluated EMG measurements after 8 weeks of vitamin D therapy in patients with chronic generalized pain, no significant improvement was found in other conductions, except for sensory amplitudes of median and ulnar nerves ${ }^{23}$. Shehab et al. found no statistically significant difference in nerve conduction values after vitamin $\mathrm{D}$ treatment for 8 weeks in diabetic peripheral neuropathic patients. They stated that Vitamin D treatment resulted in symptomatic improvement, but they attributed the lack of electrophysiologic improvement to the length of diabetes exposure and the more axonal mechanism of neuropathy ${ }^{12}$. They have mentioned that it will take more than 8 weeks to recover. Lee and Chen et al. showed that there is a decrease in VAS scores after vitamin D replacement for 3 months in diabetic neuropathic patients ${ }^{24}$.

Many previous studies show that vitamin D deficiency is present in patients with CTS. When the severity of pain was evaluated by neuropathic pain scales in these patients, pain increased $^{23,25}$. In our study, interviews with treated patients demonstrated a significant decrease in pain after treatment, like in previous studies. In fact, we obtained electrophysiologically recovery in patients with CTS. DSOL is the first parameter to response to the treatment because it is also the first parameter to be affected.

One of the most important limitations of our study is the lack of male patients and absence of a control group. We believe that further information could be gathered if the evaluation included anamnesis and examination findings. A higher number of participants could have provided more reliable results and greater statistical strength. In addition, the most important point we want to emphasize is that addition of vitamin $\mathrm{D}$ replacement to the treatment of patients in the mild to moderate stages of CTS is a symptomatic treatment and may support electrophysiological recovery. Perhaps, considering that the long-term clinical efficacy of the applied treatment modals may be different, a longer follow-up time is required.

In conclusion, our findings suggest that replacement of the necessary and adequate dose of vitamin $\mathrm{D}$ during the mild to moderate stages of CTS can both improve pain and enable electrophysiologic recovery. In addition, we suggest that, because vitamin $\mathrm{D}$ deficiency is widespread, increasing sun exposure to increase its synthesis is needed, and then, if replacement is required, the treatment should be initiated at an early period.

\section{References}

1. Nageeb RS, Shehta N, Nageeb GS, Omran AA. Body mass index and vitamin $D$ level in carpal tunnel syndrome patients. Egypt J Neurol Psychiatr Neurosurg. 2018;54(1):14. https://doi.org/10.1186/s41983-018-0009-z

2. Kleggetveit IP, Jørum E. Diagnosis of carpal tunnel syndrome. Scand J Pain. 2018;18(3):333-7. https://doi.org/10.1515/sjpain-2018-0089

3. Aboonq MS. Pathophysiology of carpal tunnel syndrome. Neurosciences (Riyadh). 2015 Jan;20(1):4-9.

4. Tanik N, Balbaloğlu Ö, Ucar M, Sarp U, Atalay T, Çelikbilek A, et al. Does vitamin D deficiency trigger carpal tunnel syndrome? J Back Musculoskelet Rehabil. 2016 Nov;29(4):835-9. https://doi. org/10.3233/BMR-160696

5. Kuru P, Akyuz G, Yagci I, Giray E. Hypovitaminosis D in widespread pain: its effect on pain perception, quality of life and nerve conduction studies. Rheumatol Int. 2015 Feb;35(2):315-22. https:// doi.org/10.1007/s00296-014-3099-7
6. Mpandzou G, Haddou EAB, Regragui W, Benomar A, Yahyaoui M. Vitamin D deficiency and its role in neurological conditions: A review. Rev Neurol (Paris). 2016 Feb;172(2):109-22. https://doi.org/10.1016/j. neurol.2015.11.005

7. Montava M, Garcia S, Mancini J, Jammes Y, Courageot J, Lavieille J-P, et al. Vitamin D3 potentiates myelination and recovery after facial nerve injury. Eur Arch Otorhinolaryngol. 2015 Oct;272(10):2815-23. https://doi.org/10.1007/s00405-014-3305-y

8. Chabas J-F, Alluin O, Rao G, Garcia S, Lavaut M-N, Risso JJ, et al. Vitamin D2 potentiates axon regeneration. J Neurotrauma. 2008 Oct;25(10):1247-56. https://doi.org/10.1089/neu.2008.0593

9. Tague SE, Clarke GL, Winter MK, McCarson KE, Wright DE, Smith PG. Vitamin D deficiency promotes skeletal muscle hypersensitivity and sensory hyperinnervation. J Neurosci. 2011 Sep;31(39):13728-38. https://doi.org/10.1523/JNEUROSCI.3637-11.2011 
10. Smolders J, Moen SM, Damoiseaux J, Huitinga I, Holmøy T. Vitamin $D$ in the healthy and inflamed central nervous system: access and function. J Neurol Sci. 2011 Dec;311(1-2):37-43. https://doi. org/10.1016/j.jns.2011.07.033

11. de Abreu DF, Eyles D, Feron F. Vitamin D, a neuro-immunomodulator: implications for neurodegenerative and autoimmune diseases. Psychoneuroendocrinology. 2009 Dec;34 Suppl 1:S265-77. https://doi. org/10.1016/j.psyneuen.2009.05.023

12. Shehab D, Al-Jarallah K, Abdella N, Mojiminiyi OA, Al Mohamedy $H$. Prospective evaluation of the effect of short-term oral vitamin D supplementation on peripheral neuropathy in type 2 diabetes mellitus. Med Princ Pract. 2015;24(3):250-6. https://doi. org/10.1159/000375304

13. Melzack R. The short-form McGill pain questionnaire. Pain. 1987 Aug;30(2):191-7. https://doi.org/10.1016/0304-3959(87)91074-8

14. American Association of Electrodiagnostic Medicine, American Academy of Neurology, and American Academy of Physical Medicine and Rehabilitation. Practice parameter for electrodiagnostic studies in carpal tunnel syndrome: summary statement. Muscle Nerve. 2002 Jun;25(6):918-22. https://doi. org/10.1002/mus.10185

15. Werner RA, Andary M. Electrodiagnostic evaluation of carpal tunnel syndrome. Muscle Nerve. 2011 Oct;44(4):597-607. https://doi. org/10.1002/mus.22208

16. McCoy EG, Boyle WF. Reinnervation of the facial muscles following extratemporal facial nerve resection. Laryngoscope. 1971 Jan;81(1):1-7. https://doi.org/10.1288/00005537197101000-00001

17. Spector JG, Lee P, Derby A. Rabbit facial nerve regeneration in autologous nerve grafts after antecedent injury. Laryngoscope. 2000 Apr;110(4):660-7. https://doi.org/10.1097/00005537200004000-00023
18. Chabas J-F, Stephan D, Marqueste T, Garcia S, Lavaut M-N, Nguyen C, et al. Cholecalciferol (vitamin D3) improves myelination and recovery after nerve injury. PLoS ONE. 2013 May;8(5):e65034. https://doi. org/10.1371/journal.pone.0065034

19. Eyles D, Almeras L, Benech P, Patatian A, Mackay-Sim A, McGrath $J$, et al. Developmental vitamin D deficiency alters the expression of genes encoding mitochondrial, cytoskeletal and synaptic proteins in the adult rat brain. J Steroid Biochem Mol Biol. 2007 Mar;103(35):538-45. https://doi.org/10.1016/j.jsbmb.2006.12.096

20. Kim K, Gong HS, Kim J, Baek GH. Expression of vitamin D receptor in the subsynovial connective tissue in women with carpal tunnel syndrome. J J Hand Surg Eur Vol. 2018 Mar;43(3):290-95. https://doi. org/10.1177/1753193417749158.

21. Banafshe HR, Khoshnoud MJ, Abed A, Saghazadeh M, Mesdaghinia A. Vitamin D supplementation attenuates the behavioral scores of neuropathic pain in rats. Nutr Neurosci. 2019 Oct;22(10):700-5. https://doi.org/10.1080/1028415X.2018.1435485

22. Neveu I, Naveilhan P, Baudet C, Wion D, De Luca HF, Brachet P. 1, 25-dihydroxyvitamin D3 regulates the synthesis of nerve growth factor in primary cultures of glial cells. Brain Res Mol Brain Res. 1994 Jul;24(1-4):70-6. https://doi.org/10.1016/0169-328x(94)90119-8

23. Akyuz G, Sanal-Toprak C, Yagci I, Giray E, Kuru-Bektasoglu P. The effect of vitamin D supplementation on pain, quality of life, and nerve conduction studies in women with chronic widespread pain. Int J Rehabil Res. 2017 Mar;40(1):76-83. https://doi.org/10.1097/MRR.0000000000000211

24. Lee SH, Gong HS, Kim D, Shin H, Kim K, Kim J, et al. Evaluation of vitamin D levels in women with carpal tunnel syndrome. J Hand Surg Eur Vol. 2016 Jul;41(6):643-7. https://doi. org/10.1177/1753193415622732

25. Demiryurek B, Gundogdu A. The effect of vitamin D levels on pain in carpal tunnel syndrome. Orthop Traumatol Surg Res. 2017 Oct;103(6):919-22. https://doi.org/10.1016/j.otsr.2017.05.003 